\title{
CELIAC DISEASE SCREENING IN PATIENTS WITH SCLERODERMA
}

\author{
Renato NISIHARA ${ }^{1}$, Shirley Rosa UTIYAMA ${ }^{1}$, Pedro Ming AZEVEDO² and Thelma Larocca SKARE ${ }^{2}$
}

\begin{abstract}
Both celiac disease and scleroderma have autoimmune etiology and affect the bowel causing diarrhea. As an association of autoimmune disease in a single individual is not rare, it is important to know if a patient with scleroderma may also have celiac disease. To analyze this we studied 105 scleroderma patients and 97 volunteers for IgA-EmA by indirect immunofluorescence assay. We could not find a higher prevalence of this autoantibody in scleroderma patients. The authors conclude that there is no need to screen scleroderma patients with diarrhea for celiac disease unless there is a clear clinical indication for this.
\end{abstract}

HEADINGS - Celiac disease. Scleroderma, systemic.

\section{INTRODUCTION}

Aggregation of autoimmune diseases is frequently observed in clinical practice. There is no clear cut explanation for this although it is noted that autoimmune diseases may share a genetic background. In addition, an exposure to a common etiological trigger agent is also possible ${ }^{(1)}$.

Celiac disease $(\mathrm{CD})$ is a chronic, inflammatory and immunological mediated gluten-dependent enteropathy disease that occurs in genetically susceptible individuals ${ }^{(2)}$. It appears in association with other organ specific autoimmune diseases such as thyroiditis, diabetes mellitus, dermatitis herpetiformis, autoimmune miocarditis, Addison disease, autoimmune hepatitis and primary biliary cirrhosis, etc ${ }^{(2)}$.

$\mathrm{CD}$ is also associated albeit occasionally with systemic autoimmune disorders such as connective tissue disorders ${ }^{(1)}$. In this context, Sjögren syndrome is probably the connective tissue disease that bears the more convincing data. Iltanen et al. ${ }^{(1)}$ studying 34 Sjogren's syndrome patients found that $14.7 \%$ had $\mathrm{CD}$, a prevalence of 30 to 40 fold higher than observed in the normal population. It is known that Sjögren's syndrome shares the HLA DQ2 and DQ8 haplotype with $\mathrm{CD}$. On the other hand, no association has been found with rheumatoid arthritis ${ }^{(1)}$. Association of CD with polymyositis is less studied and described in case reports $^{(1)}$; as CD is a common disease, this relationship may be coincidental.

In scleroderma ( $\mathrm{SSc}$ ), association with $\mathrm{CD}$ is controversial. Luft et al. ${ }^{(3)}$ studying IgA antitissue transglutaminase antibody (anti-tTG) in $30 \mathrm{SSc}$ patients found that $2(7 \%)$ of them had this antibody against $(2 / 40) 4 \%$ of normal population $(P=\mathrm{NS})$. Rosato et al. ${ }^{(4)}$ analyzing $50 \mathrm{SSc}$ patients found a prevalence of anti-tTG in $5 / 50$ of their patients although only 4 (8\% of the total sample) had biopsy proven CD a value that is higher than in normal population.

$\mathrm{SSc}$ is associated with diarrhea due to loss of peristalsis by fibrous involvement of smooth muscle and intraluminal bacterial overgrowth and the clinical findings of diarrhea and malabsorption mimics $\mathrm{CD}^{(5)}$. Nevertheless, the treatment of these two entities is completely different, which emphasized the need for a correct differential diagnosis.

Nowadays, endomysium antibodies (IgA-EmA) are currently regarded as the most sensitive and specific immunologic marker of $\mathrm{CD}^{(2)}$. IgA-EmA as well as anti-tissue transglutaminase (anti-tTG) has allowed evaluating the potential risk for $\mathrm{CD}$ in individuals with suggestive symptoms and in high risk populations. IgA-EmA antibody has over $90 \%$ specificity and sensibility for $\mathrm{CD}$ diagnosis. The titer of these antibodies is related to the degree of intestinal atrophy and symptoms severity ${ }^{(2)}$.

In this context we studied 105 scleroderma patients from Southern Brazil for the presence of EmA-IgA antibodies.

\section{METHODS}

One hundred and five scleroderma patients were included in this study. In this sample $7.6 \%$ were male and $92.3 \%$ female; mean age of 43.2 years and mean disease duration of 7.7 years. In this sample, $36 / 105$ $(34.2 \%)$ had diffuse scleroderma; $9 / 105(8.5 \%)$ had the mixed form (SSc plus myositis), $1(0.9 \%)$ was sine scleroderma and 59/105 (56.2\%) had the limited form (CREST syndrome). 
After formal consenting, blood was collected and the serum aliquoted and stored at $-80^{\circ} \mathrm{C}$ until performing tests.

As control, we studied 97 healthy volunteers from the same geographical region matched for age and sex. Tests for $\operatorname{IgA-EmA~were~performed~by~indirect~immunofluorescence~}$ assay, using human umbilical cord as substract and fluorescein conjugated goat anti-human IgA (GMK, Porto Alegre, RS, Brazil) as conjugate. Positive and negative controls were included in each test battery (Figure 1).

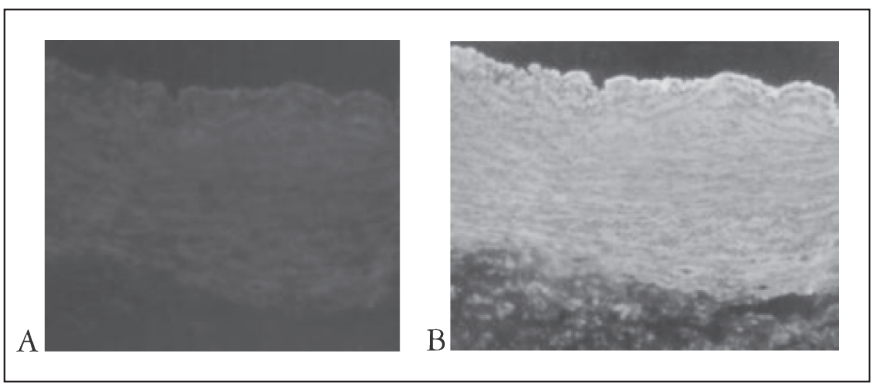

FIGURE 1. A - Negative IgA-EmA in cryostatic section of human umbilical chord (400X). B - Positive IgA-EmA in cryostatic section of human umbilical chord (400X)

\section{RESULTS}

All samples, patients and controls were negative for IgA-EmA.

\section{DISCUSSION}

Crypt hyperplasia, villous atrophy and intra epithelial lumphocytic infiltration are the main pathological characteristics of CD. CD patients classically develop prolonged diarrhea, abdominal pain and weight loss, iron or folate deficiency, osteoporosis, chronic fatigue, milk intolerance, dental problems, neuropathy, dementia and failure to thrive. Subclinical forms are quite common; it is not rare that CD patients with minor gastroenterological symptoms are misdiagnosed as having irritable bowel disease or that CD diagnosis is only detected after the investigation of iron deficiency anemia or low bone mass (osteoporosis/osteopenia) ${ }^{(2)}$.

Bowel disease is the second most common involvement in scleroderma, next to skin, and has a high variable severity. Fibrous infiltration of small bowel results in dilated and often atonic loops that loose their propulsive function. Bacterial overgrowth causes damage of mucous layer causing malabsorption and malnutrition ${ }^{(5)}$.

In our study we could not prove association of SSc and CD. Our results are in contrast with those from Rosato et al.(4). Differences in genetic background may be one explanation for this finding. Although the prevalence of $\mathrm{CD}$ in our geographical region is the same as worldwide $(0.3 \% \text { to } 0.5 \%)^{(2)}$, we do not have enough knowledge of the genetic background of scleroderma Brazilian patients. One more data to be taken into account is that our sample had a small proportion of generalized SSc form - that was the only form associated with CD in the previously cited study. Sample size may be another explanation for the discordant results. SSc is a quite rare disorder, affecting 286 per million population and $\mathrm{CD}$, as already mentioned, is a very common one. In this context multicentric studies with larger samples may answer this question.

Concluding, in our sample of 105 Brazilian patients there is no detected association between scleroderma and IgA-EmA presence.

Nisihara R, Utiyama SR, Azevedo PM, Skare TL. Triagem para doença celíaca em pacientes com esclerodermia. Arq Gastroenterol. 2011;48(2):163-4.

RESUMO - Tanto a esclerodermia como a doença celíaca são doenças de autoimunidade que causam diarreia. Como o agrupamento de doenças autoimunes em único indivíduo não é raro, é importante saber se um individuo com esclerodermia tem maiores chances de ter ou não doença celíaca. Para isso, estudaram-se 105 pacientes com esclerodermia e 97 controles saudáveis para o anticorpo EmA IgA. Não foi possível detectar presença aumentada de EmA IgA em pacientes com esclerodermia. Conclui-se que não existe necessidade de busca ativa de doença celíaca em pacientes com esclerodermia e diarreia, a menos que existam evidências clínicas claras da doença.

DESCRITORES - Doença celíaca. Escleroderma, sistêmico.

\section{REFERENCES}

1. Iltanen S, Collin P, Korpela M, Holm K, Partanem J, Polvi A, Mäki M. Celiac disease and markers of celiac disease latency in patients with primary Sjögren's syndrome. Am J Gastroenterol. 1999;94:1042-6.

2. Kotze LM. Doença celíaca. In: Coelho JCU, editor. Aparelho Digestivo Clínica e Cirurgia. $3^{\mathrm{a}}$ ed. São Paulo: Atheneu; 2005. v.2, p. 703-24.

3. Luft LM, Barr SG, Martin LO, Chan EK, Fritzler MJ. Autoantibodies to tissue transglutaminase in Sjögren's syndrome and related rheumatic diseases. J
Rheumatol. 2003;30:2613-9.

4. Rosato E, De Nitto D, Rossi C, Libanori V, Donato G, Di Tola M, Pisarri S, Salsano F, Picarelli A. High incidence of celiac disease in patients with systemic sclerosis. J Rheumatol. 2009;36:965-9.

5. Varga J. Systemic sclerosis: epidemiology, pathology and pathogenesis. In: Klippel JH, Stone J, Crofford LJ, White PH, editors. Primer on rheumatic diseases. $13^{\text {th }}$ ed. Atlanta: Springer Science-Business Media LLC; 2008. p.351-8.

Received 26/4/2010 Accepted 15/10/2010. 